\title{
To What Extent is McDonaldization Detrimental to Our Society?
}

\author{
QiJia HuangChen
}

Brown University, Providence, RI 02912, USA, qijia_huangchen@brown.edu

\begin{abstract}
In his book the McDonaldization of Society, George Ritzer describes the process of McDonaldization in which more and more businesses, presumably influenced by the astonishing success of the McDonald's, seek to promote "efficiency, calculability, predictability, and control". He points out that the process is potentially detrimental and dehumanizing, arguing from a Weberian perspective that the rationality itself may cause irrationality. While it is true that the irrationality discussed by Ritzer can be both seen and imagined, such situation seems possible rather than necessary. Ritzer's account, therefore, seems to lack a normative and conceptual value. In reality, the social issue raises public concern and requires immediate attention. McDonaldization seems to bring great harm to the society, as $2019 \mathrm{Netflix}$ documentary called American Factory reflects the problem in reality. In the documentary, the workers are forced to devote themselves to highly industrialized productions. They are trained to work for hours, doing repetitive and uninteresting labour, and often under the condition of high temperature with a risk of being hurt. In this case, question remains regarding the negative impact that McDonaldization has on our society. This essay investigates McDonaldization from a more theoretical framework, and approaches the question through the perspective of the theory of alienation.
\end{abstract}

Keywords: McDonaldization, Modernity.

\section{INTRODUCTION}

In his book the McDonaldization of Society, George Ritzer describes the process of McDonaldization in which more and more businesses, presumably influenced by the astonishing success of the McDonald's, seek to promote "efficiency, calculability, predictability, and control" [1]. He points out that the process is potentially detrimental and dehumanizing, arguing from a Weberian perspective that the rationality itself may cause irrationality [2]. While it is true that the irrationality discussed by Ritzer can be both seen and imagined, such situation seems possible rather than necessary. Ritzer's account, therefore, seems to lack a normative and conceptual value. Question remains regarding the negative impact that McDonaldization has on our society. In this essay, I will investigate McDonaldization from a more theoretical framework, and try to answer the question through the perspective of the theory of alienation.

\section{THE PHENOMENON}

McDonaldization seems to bring great harm to the society, as 2019 Netflix documentary called American
Factory reflects the problem in reality. In the documentary, the workers are forced to devote themselves to highly industrialized productions. They are trained to work for hours, doing repetitive and uninteresting labour, and often under the condition of high temperature with a risk of being hurt. In addition, such an industry not only keeps the workers under enormous pressure, but also causes the managers to be anxious about their deed. "When I look back," a Chinese manager who runs part of the business exclaims, "on what we have done, I marvel at the progress that we have made just as much as I wonder whether it is the right thing to do." He reflects on the potential damage to the environment and the suffer that all who relate to the factory have been through, and, in front of the camera, he sighed with emotion [3].

Terming the potential paradox of McDonaldization as the 'irrationality of rationality', Ritzer presents the detail of the severity of the issue. According to him, the negative aspects of McDonaldization are not limited to the practically unachievable ideals. It is also crucial to consider that the success of such business mode itself brings harm to the society, resulting in "false friendliness, 
excessively high cost, health and environmental dangers, and homogenization" [1].

Firstly, the practical failure of McDonaldization is depicted by Ritzer to be an unexpected distort of the idealized intentions: though the companies indeed originally designed to function in a highly industrialized way, as to ensure "efficiency, calculability, predictability, and control", they, in reality, often fail to keep up with the mode of production, causing the business to stray from the promises. Ritzer illustrates his point using the example of a customer waiting in line of a fast-food restaurant. While both the producer and the consumer should agree with each other regarding the assumed value of efficiency under this circumstance, the consumer actually may not be able to complete the purchase without wasting time in a line. In this case, the restaurant's actual service does not commit to the preassumed notion of efficiency, a crucial idea that is implicitly promised if the business is a 'fast-food' restaurant, and the customer's choice of going to the restaurant to save time, which seems rational in the first place, would be made irrational in the end. Further, such an example can be seen in a broader context. As Ritzer points out, the "just-in-time" industry in Japan has create inefficiency by causing heavy traffic in the city on a large scale, resulting the inhabitants in the city to face inefficiencies more frequently in their daily life in general. Thus, the rational pursuit for efficiency ends up irrationally contributing to the even greater inefficiency, creating a significant negative externality to the society [1].

Also, Ritzer highlights the incidental social problems which come with McDonaldization, providing details specific to the discussion the "extra cost", "false friendliness", "health and environmental dangers," and "homogenization". According to him, even if we assume that the McDonaldized industry is efficient, it often requires consumers to pay an additional price, as moreMcDonaldized companies tend to charge the customers for prices which are higher than the market price. With reference to Richard Cohen's account of his ATM experience, Ritzer demonstrates that the processing fee of the ATMs would be such an extra illegitimate charge. Also, McDonaldization restricts many genuine interactions between people, for, even if there are employees working in the industry, they are treated as no more than machines, and are asked to perform simple and repetitive tasks. What Ritzer demonstrates as the health and environmental dangers are even more worthy of wide social attention. Because, though indirectly, it is indeed the success of the fast-food industry that poses a threat to people's traditional, natural, and thus healthy lifestyles, and, meanwhile, causes problems such as air pollution, water shortage and land degradation. Finally, Ritzer criticizes the homogenization at the core of McDonaldization, explaining that the products produced through such industry is to substitute products which have cultural values, and, thus, reducing culture, traditions, and diversities all around the world [1].

In this way, Ritzer's account indicates the damage that McDonaldization has done to our society: it not only tends to fail in its own course of promoting efficiency, but it would also create potential threats to the existing order.

\section{THE CONCEPT}

But Ritzer's analysis of the "irrationality of the rationality" might seem superfluous, as the situations discussed remain mostly descriptive. For example, such empirical evidence can indeed be found that people spend time waiting before they can order in fast-food restaurants, but it is not hard to argue otherwise. After all, people do not always waste time in a fast-food restaurant, and, more importantly, whether waiting to make order should be considered inefficiency is left to be determined, for the restaurant might still be saving people's time if the services-ordering, cooking, etc- - are efficient enough. Empirical evidences and descriptions seem to lack power that can convince people of the severity of the social problem here. Ritzer's description, therefore, can be a mere possibility rather than necessity. Even though he provides a vivid account for the problems, with figures and situations presented in the book, doubts may still be raised regarding the harm that McDonaldization has done to the society. A more conceptual analysis can be helpful in order to point out the exact social problem indicated by the process of modernity.

Such a conceptual analysis may be found in Marx's works. In his early years, Karl Marx undertakes to conceptualize modernity, providing a theoretical framework for the discussion of conceptions such as properties, money. At the center of Marx's account of modernity is the idea of alienation, which has its origin in Hegelian thoughts. Alienation seems to be a crucial concept when theorizing the harm of modern industrialization, since it opens the discussion of labour, independence, and equality [4,5].

The concept of alienation roots in the Hegelian insight of "self-consciousness", which is explored regarding the master and slave problem [6]. In his book the Phenomenology of Spirit, Hegel introduces the conception of the master and slave problem, suggesting that every consciousness must seek recognition in the other in order to establish itself. He claims that the selfconsciousness seeks to detach from the material world in order to be pure, and it would choose to engage in a fight with the other, showing its independence from both the material body of its own and the other's. Then, according to Hegel, the conflict would be resolved when both consciousness realize that the result of the fight - the death of either-is beneficial to no one. The "victor" would decide to spare the "loser", preserving the 
recognition from the other consciousness, and, meanwhile, unbalancing the original equality. Now, the victor who is independent in this situation is the master, and the loser, dependent of the victor, is the slave. While the master acquires recognition from the slave, the slave may only work in the material work in order to gain adequate acknowledgment of his own consciousness. In this way, Hegel's account of the master and slave problem illuminates the discussion on independence, inequality, and consciousness. For Hegel, alienation is crucial to our mind [7].

While the Hegelian concept of alienation is deemed to be mainly intellectual, or psychological, Marx builds on the concept, claiming that it is a problem that is "real" and "concrete". He introduces the notion of "estranged, alienated labour" in the Economic and Philosophical Manuscripts, methodologically pointing out four different aspects of alienation:

1) The alienation of the product

2) The alienation of the activity

3) The alienation from human nature

\section{4) The alienation from the other men}

Marx starts by examining the relations between the worker and the product, as well as the production, constructing the first two aspects of alienated labour. According to him, as a worker labours to produce, the products, once being made, exists independently as a material substance alien to its producer. Marx claims that "the realization of labour is its objectification", and that, being objectified, the product then marks "a loss of reality" for the worker since a part of his inner world is devoted to the material otherness. Also, while labouring, the workers are contributing to the products, producing privation for themselves and empowerment of the products. "The greater this product, the less is he himself." The more the workers exert labour to the production, the more they are "dominated" by the products. In this case, not only does the product stands for the estranged "other" to the worker, but it also "confronts" the worker as "powerful" and "hostile". Following this first aspect, Marx points out that, since it is demonstrated that the product alienates the worker, the production process, as it is what is simply resumed by the product, should also mean alienation to the worker. He claims that the production is the "alienation of labour", pointing out that the labour is "forced", and thus can be a denial to the worker's human self [8].

The third aspect is then deduced from the previous discussions. Marx indicates that, since forced labour of production creates the sense of self-estrangement in the workers, causing the paradoxes of "activity as passivity, power as impotence, procreation as emasculation", such labour drives humans away from not only their nature, but also themselves. In Marx's view, human beings link both physically and naturally to the nature, constituting a "universal" and "free" being, and it is the consciousness of such being that distinguishes humans from animals. In other words, a part of human nature is the capability of being consciousness of their activities. However, when performing alienated labour, the workers are doing mindless production. Such forced labour cannot be generated from a free consciousness, and it alienates man from his nature by reversing "his individual life" to be "a means" for his "species-life." Then, the fourth aspect of alienated labour is explained as a consequent of the third aspect. Because the worker, under the influence of mindless labour, lives only as a species-being, the relation between men would no longer be spiritual connection either, but would be reduced to exchanges on a material and superficial level. "In general," Marx summarizes, "the proposition that man is estranged from his species-being means that each man is estranged from the others and that all are estranged from man's essence." [9]

In this case, Marx presents the concept of alienated labour in a thorough and theoretical way. A close examination might indicate that this Marxism framework can be applied to evaluate the negative impacts of McDonaldization.

McDonaldization certainly involves the first two aspects that Marx attributes to alienated labour. It is not hard to see that the theory corresponds comprehensively to various situations that are to be found in reality. Firstly, the workers participated in McDonaldized industry devote themselves to massive productions, exerting their labour to the realization of the products which are only alienated from themselves. Worse, the workers each might only be in charge of a specific stage of the production, and may not even see the products being actually produced. Such situations, which are not rarely seen, seem to further exacerbate the workers' alienation to the products. And, the products, being the realization of massive production, is even more empowered and dominated compared to the worker, oppressed and unappreciated. In addition, the "efficiency" which can be achieved through the labour of the workers is also almost unrelated to the workers. No matter how much efficiency a worker's labour has created, he is not the owner of the "product". Secondly, the production process is usually "forced labour" for the workers in the industry. McDonaldized production activities are originally characterized as "predictable" as well as "controllable", and these are exactly the traits that constitutes the workers' repetitive and uninteresting work. The workers, receiving minimal wage and having little rest, are often restrained to work unwillingly, and therefore denying their true selves.

The third aspect, which is the alienation from the human nature, requires a rather abstract analysis of the situation. In order to testify that the McDonaldization 
reality corresponds to Marx's claim and therefore should be seen as alienated labour, we need to examine the situation with regard to its influence on the worker's nonmaterial thoughts and feelings. It can be difficult to imagine whether labour can have a significant influence on human mind. But such an account is found in Ritzer's description, "cold, mechanical systems are usually the antithesis of the dream worlds associated with enchantment." Ritzer terms the situation as "disenchantment", borrowing the Weberian idea that "the Western world has grown increasingly disenchanted." [1] Since the Weberian theory tends to put an emphasis on people's thoughts throughout history-the theory considers modernization as a process of rationalizationsuch evidence testifies greatly that the dull labour undermines the workers' conscious thinking, a distinguishing part of human nature that separates them from animal species. Also, referring back to Ritzer's description of "false friendliness", we may find that the fourth and final aspect of Marx's theory of alienated labour is well testified. What is called "false friendliness" is exactly a kind of alienation between men, as the genuine mutual recognition or interaction is gradually substituted by the material and superficial exchange.

Now, we have reached the conclusion that McDonaldization can be considered a form of Marxism alienation, and is therefore malevolent to the working class. Marx's account provides a more conceptualized insight of the issue of McDonaldization. It differs from Ritzer's account in that, not only does it introduce and explain the harm in a normative way, but it also indicates a clear agency when examining the comprehensive social problem. When illustrating the concept of alienation, Marx is mainly analyzing the situation with a focus on the workers, whom in his other works he refers to as the class of "proletariats". In a sense, Marx not only develops a superficial and empty theory, but he also aims to make harsh criticism of the situation from a meaningful standpoint. He targets the end of the alienated labour and the overturn the current situation, describing the oppression of alienated labour to be the suffering of capitalism, and seeks to find a practical solution. According to him, "Communism ...... it is the genuine resolution of the conflict between man and nature, and between man and man, the true resolution of the conflict between existence and being, between objectification and self-affirmation, between freedom and necessity, between individual and species. It is the solution of the riddle of history and knows itself to be the solution." [9] In this case, Marx ambitiously rejects the idea of promoting wage, insisting that only by abolishing private property and the wage system can men be liberated [6].

\section{CONCLUSION}

To sum up, Ritzer provides a detailed description of the negative aspects of McDonaldization in modern society, and Marx's theory on the alienated labour offers a theoretical framework to analyze the phenomenon. While the two approaches differ, both Ritzer and Marx agree that industrialized production such as McDonaldization would cause great social problems.

Further, question can be raised regarding the doubt of Marx's belief that the capitalist mode of production must be overturned. Dismissing the idea of historical materialism, Weber claims an alternative that the capitalist economy, which represents, in his view, the highly developed rationality, is to last and to triumph. According to him, "a modern technological society would rely upon an efficient bureaucracy, and that any problems would not be of structure but management and competence." Weber's account of this social problem dissent from Marx's, presenting the modern society to be an "iron cage" of economic calculations [10]. As a matter of fact, either theory alone would probably present the study of modernity as a more straightforward situation, but only with the collective effort can the unexplained assumptions be removed and the specific characteristics be accounted for. It is therefore important that we accept the complex collaboration, as we should acknowledge the natural complexity of the social problem of McDonaldization.

\section{REFERENCES}

[1] Ritzer, G. (2011). The McDonaldization of society 6. Los Angeles, CA: Sage.

[2] Weber, Max, et al. The Protestant Ethic and the "Spirit" of Capitalism and Other Writings. Penguin Books, 2002.

[3] American Factory. (2019, August 21). Retrieved November 2, 2020, from https://www.netflix.com/

[4] Wolff, J. (2017, April 12). Karl Marx. Retrieved November $\quad 02, \quad 2020, \quad$ from https://plato.stanford.edu/entries/marx/

[5] Singer, P. (2018). Marx: A very short introduction. Oxford, United Kingdom: Oxford University Press.

[6] Leopold, D. (2018, August 30). Alienation. Retrieved November 02, 2020, from https://plato.stanford.edu/entries/alienation/

[7] Singer, P. (2001). Hegel: A very short introduction. Oxford: Oxford University Press.

[8] Marx, K. (1961). Economic and philosophical manuscripts. Place of publication not identified: Lawrence \&amp; Wishart.

[9] Marx. (1843). Retrieved November 02, 2020, from https://www.marxists.org/archive/marx/works/184 3/critique-hpr/intro.htm

[10] The Sociology Book. (2015). London: Dorling Kindersley Limited. 